\title{
URGENSI KRIMINALISASI KUMPUL KEBO (COHABITATION) DALAM HUKUM PIDANA INDONESIA
}

\author{
Budi Sulistiyono \\ Email: rafi_sulistiyono@yahoo.com \\ Kejaksaan Negeri Jakarta Utara \\ Hari Purwadi \\ Email: h_purwadie@yahoo.com
}

Hartiwiningsih

Email: hartiwi50@yahoo.com

Dosen Fakultas Hukum Universitas Sebelas Maret Surakarta

\begin{abstract}
This article aims to know the criminal law policy against the current kebo gathering and to know the criminal law formulation policy against kebo assemble in the future. This research is a type of normative legal research using conceptual approach. The legal substances used in this study are primary legal materials and secondary legal materials. This legal material analysis technique uses deductive analysis techniques by determining the major premise and minor premise to draw a conclusion or conclusion of the proposed problem. The results of this study indicate the need for a criminal law formulation policy in the form of criminalization of kebo kebo practices in Indonesia.
\end{abstract}

Keyboard: formulation policy, criminal law, cohabitation

Abstrak

Artikel ini bertujuan untuk mengetahui kebijakan hukum pidana terhadap kumpul kebo saat ini dan untuk mengetahui kebijakan formulasi hukum pidana terhadap kumpul kebo di masa mendatang. Penelitian ini berjenis penelitian hukum normatif yang menggunakan pendekatan konseptual. Bahan hukum yang dipergunakan di dalam penelitian ini adalah bahan hukum primer dan bahan hukum sekunder. Teknik analisis bahan hukum ini menggunakan teknik analisis deduktif dengan menentukan premis mayor dan premis minor untuk menarik suatu konklusi atau simpulan dari permasalahan yang diajukan. Hasil penelitian ini menunjukkan perlu adanya kebijakan formulasi hukum pidana berupa kriminalisasi terhadap perbuatan kumpul kebo di Indonesia di masa mendatang.

Keyword: kebijakan formulasi, hukum pidana, kumpul kebo 


\section{A. Pendahuluan}

Kumpul kebo kini mulai marak di kota-kota besar Indonesia, hal ini oleh masyarakat dianggap telah merusak rasa kesusilaan masyarakat Indonesia. Berdasarkan survei Pusat Studi Wanita Universitas Islam Indonesia (PSW-UII) Jogjakarta tahun 2001, pola hidup seks bebas di kalangan anak remaja secara umum dan di pondokan atau kos-kosan, khususnya di daerah Kota Jogjakarta, berkembang semakin serius dengan makin longgarnya kontrol yang mereka terima. Sehingga, makin banyak remaja yang terjebak ke dalam pola hidup seks bebas (kumpul kebo) karena berbagai pengaruh yang mereka terima. Pada tahun 2002, pernah dipublikasikan hasil survei Lembaga Studi Cinta dan Kemanusiaan serta Pusat Pelatihan Bisnis dan Humaniora (LSCK PUSBIH) terhadap mahasiswa Jogjakarta. Penelitian itu dilakukan selama tiga tahun, mulai Juli 1999 hingga Juli 2002, dengan melibatkan sekitar 1.660 responden yang berasal dari 16 perguruan tinggi, baik negeri maupun swasta di Jogjakarta. Dari 1.660 responden itu, 97, 05 persen mengaku sudah hilang keperawanannya saat kuliah, karena pernah melakukan seks berpasangan atau kumpul kebo. Ditinjau dari tempat mereka melakukan seks bebas, sebanyak 63 persen melakukan seks bebas di tempat kos pria pasangannya.Sebanyak 14 persen dilakukan di tempat kos putri atau rumah kontrakannya.Selanjutnya21 persen di hotel kelas melati yang tersebar di Jogjakarta dan 2 persen lagi di tempat wisata yang terbuka. Data di atas menujukkan bahwa tempat kos-kosan telah menjadi sarang kumpul kebo(http://www.kompas.com/kompascetak/0108/01/daerah/anca19.html,diakses pada tanggal 11 juni 2017).

Dari berbagai macam penyelenggaraan kesejahteraan masyarakat serta kepentingan umum yang hendak dilindungi oleh hukum (sebagai kepentingan hukum) salah satunya adalah rasa kesusilaan masyarakat. Bangsa Indonesia yang telah terkenal dengan budayanya yang tinggi serta menjunjung tinggi nilai-nilai kesusilaan dalam kehidupannya sehari-hari, kini mulai mempersoalkan timbulnya fenomena baru dalam kehidupan bermasyarakatnya, yaitu berupa penyimpangan 
kehidupan di bidang kejahatan seksual. Penyimpangan kesusilaan itu salah satunya adalah perbuatan kumpul kebo. Perbuatan kumpul kebo diartikan sebagai "hidup bersama tanpa adanya ikatan suatu perkawinan yang terjadi antara seorang pria dan wanita dimana mereka sama-sama belum menikah atau yang kita kenal dengan kumpul kebo"(Barda Nawawi Arief, 2011: 300).Perbuatan yang oleh masyarakat disebut "kumpul kebo" hakikinya bertentangan dengan nilai yang hidup dalam perikehidupan masyarakat itu sendiri. Nilai yang hidup dalam perikehidupan masyarakat meyakini, bahwa hidup bersama berlainan jenis dan sama-sama dewasa harus diikat oleh pernikahan. Pernikahan merupakan "ikatan suci" (mengandung nilai kesucian) yang menjadi landasan terbentuknya keluarga sejahtera lahir dan bathin yang dalam bahasa Islamnya sebagai keluarga "sakinah, mawadah dan rahmah". Inilah perlunya hukum melindungi "nilai kesucian" perkawinan dengan melakukan kriminalisasi terhadap kumpul kebo. (Eko Soponyono, 2013: 196)

Sudikno Mertokusumo mengatakan bahwa disamping kaidah kepercayaan atau agama, kaedah kesusilaan dan kaedah sopan santun masih diperlukannya suatu kaedah hukum. Kaedah hukum ini melindungi lebih lanjut kepentingankepentingan manusia yang sudah mendapat perlindungan dari ketiga kaedah lainnya dan melindungi kepentingan-kepentingan manusia yang belum mendapat perlindungan dari ketiga kaedah tadi. (Sudikno Mertokusumo, 2008:12).

Oleh karena itu butuh adanya suatu respon yang berupa suatu aturan hukum sebagai alat untuk mengatasi suatu perbuatan yang dianggap menyimpang oleh masyarakat, sehingga masyarakat memandang perlu adanya sanksi yang berupa sanksi pidana, sebagai sarana yang dapat melindungi masyarakat dari kejahatan atau sarana untuk penanggulangan perbuatan yang menyimpang. Hukum pidana merupakan suatu "aturan hukum yang mengikatkan kepada suatu perbuatan yang memenuhi syarat-syarat tertentu sebagai akibat yang berupa pidana”. (Sudarto, 2009:13). 
Namun kenyataannya hingga sekarang ini hukum pidana belum menyentuh pengaturan mengenai kumpul kebo (cohabitation) sebagai suatu tindak pidana (delik) yang sering disebut sebagai proses kriminalisasi. KUHP Indonesia yang berlaku sampai dengan saat ini adalah masih KUHP Belanda yaitu Wetboek Van Straftrecht yang diterjemahkan dan diberlakukan di Indonesia dengan menggunakan asas konkordansi. Sehingga di dalam KUHP Belanda zaman colonial itu tidak mengatur mengenai kumpul kebo suatu tindak pidana oleh karena sebagai negara barat, Belanda menganut liberalisme yang memberikan kebebasan individual bagi setiap warga negaranya.

Oleh karenanya Sahetapy menganalogikan KUHP sebagai berikut : "Met die Code Penal (baca W.v.S.Ned.) ging het al seen broek die eerst door vader wordt gedragen, dan overgaat op den oudsten en vervolgens met een lap er op, op den tweede zoon”. Yang artinya adalah : "Code Penal (baca KUHP) bagaikan sebuah celana yang dulu dipakai oleh ayah, kemudian beralih kepada anak yang sulung dan selanjutnya dengan tambalan sepotong kain yang diteruskan kepada anak yang kedua”. Itulah KUHP Belanda yang asalnya dari Prancis yang sekarang dipakai di Indonesia(Komisi Yudisial, 2010 : 120).

Oleh karena itu di dalam Pembaharuan hukum khususnya hukum pidana, harus bernafaskan kepada jiwa nasional dan nilai-nilai yang ada dalam kehidupan nasional yang berkeadilan bagi seluruh masyarakat. Hal ini didukung oleh sebuah "literatur hukum Belanda yakni "Recht als model van rechtvaardigheid", yang menyatakan bahwa usaha untuk mengejar keadilan merupakan alat bantu paling penting dalam pelaksanaan hukum". (Komisi Yudisial, Loc Cit, 2010: 130). Hal itu menggambarkan apabila kita menamakan Negara Indonesia adalah Negara hukum, makadengan sendirinya kita mengatakan bahwa hukum itu adalah rule of just law atau hukum yang adil.

Pembaharuan hukum pidana dapat dilakukan melalui suatu kebijakan hukum "berorientasi untuk mewujudkan peraturan-peraturan yang baik sesuai dengan keadaan dan situasi pada suatu waktu”. (Soedarto, 1981: 159). Kebijakan 
hukum dapat dilakukan dengan berbagai macam cara, salah satunya yaitu dengan mengadakan suatu pembaharuan hukum pidana terhadap sistem hukum pidana yang selama ini ada di beberapa Negara (terutama yang berasal/di impor dari hukum asing semasa zaman kolonial).

Pembaharuan Hukum Pidana di Indonesia tentu tidak terlepas dari politik hukum yang bertugas untuk meneliti perubahan-perubahan yang perlu diadakan terhadap hukum yang ada agar memenuhi kebutuhan-kebutuhan baru di dalam masyarakat. Politik hukum tersebut meneruskan suatu perkembangan tertib hukum, dari "Ius Constitutum" yang bertumpu pada kerangka landasan hukum yang terdahulu menuju kepada penyusunan "Ius Constituendum" atau hukum pada masa yang akan datang.

Maka penulis dalam artikel ini akan membahas mengenai kebijakan hukum pidana terkait dengan krininalisasi perbuatan kumpul kebo (cohabitation) dengan merumuskan masalah sebagai berikut: Bagaimanakah kebijakan hukum pidana terhadap perbuatan kumpul kebo saat ini? Bagaimanakah kebijakan formulasi hukum pidana terhadap perbuatan kumpul kebo di masa mendatang.

\section{B. Metodologi}

Penelitian ini termasuk dalam jenis penelitian hukum doktrinal. Penelitian hukum doktrinal adalah penelitian-penelitian atas hukum yang dikonsepkan dan dikembangkan atas dasar doktrin yang dianut sang pengkonsep dan/atau sang pengembangnya. (Sulistiawati Irianto dan Shidarta, 2013: 121).Pendekatan konseptual digunakan manakala peneliti tidak beranjak dari aturan hukum yang ada. Hal itu dilakukan karena memang belum atau tidak ada aturan untuk masalah yang dihadapi ((Sulistiawati Irianto dan Shidarta, 2013: 137).Bahan hukum atau data sekunder didalam penelitian hukum diperinci dalam berbagai macam tingkatan yaitu: (Mukti Fajar Nur Dewata dan Yulianto Achmad, 2010:109).

1. Bahan hukum primer, bahan hukum yang terdiri atas peraturan perundangan, risalah resmi, putusan pengadilan, dan dokumen resmi negara. 
2. Bahan hukum sekunder, bahan hukum yang terdiri atas buku atau jurnal hukum yang berisi mengenai prinsip-prinsip dasar (asas hukum), pandangan para ahli hukum (doktrin), hasil penelitian hukum, kamus hukum, dan ensiklopedi hukum.

3. Bahan non hukum adalah bahan penelitian yang terdiri atas buku teks bukan hukum yang terkait dengan penelitian seperti buku politik, buku ekonomi, data sensus, laporan tahunan perusahaan, kamus bahasa, dan ensiklopedi umum.

Teknik pengumpulan bahan hukum yang dipergunakan dalam penelitian hukum ini adalah melalui studi kepustakaan atau library research. Penulis mengumpulkan bahan hukum yang berupa bahan hukum primer dan bahan hukum sekunder, dan mempelajarinya untuk mendapatkan jawaban atas permasalahan yang menjadi titik sentral atau urgensi dalam suatu penelitian hukum.Penulisan ini menggunakan teknik analisis bahan hukum deduktif. Logika deduktif (Mukti Fajar Nur Dewata dan Yulianto Achmad, 2010: 109) atau sering kali disebut sebagai cara berpikir analitik mempunyai pengertian adalah : cara berpikir yang bertolak dari pengertian bahwa sesuatu yang berlaku bagi keseluruhan peristiwa atau kelompok/jenis, berlaku juga bagi tiap-tiap unsur di dalam peristiwa kelompok/jenis tersebut.Dalam penggunaannya, logika deduktif ini memerlukan alat yang disebut silogisme. Silogisme adalah (Mukti Fajar Nur Dewata dan Yulianto Achmad, 2010: 110) sebuah argumentasi yang terdiri dari 3 (tiga) buah proposisi berupa pernyataan yang membenarkan atau menolak suatu gejala. Proposisi-proposisi tersebut disebut premis mayor, premis minor, dan konklusi. Premis mayor adalah merupakan ketentuan umum, premis minor adalah faktafakta yang bersifat khusus, dan konklusi adalah upaya untuk menarik kesimpulan hubungan antara premis minor dan premis mayor.

\section{Hasil dan Pembahasan}

\section{Praktik Penegakan Hukum dalam Penanggulangan Perbuatan Kumpul Kebo (Cohabitatation)}


Permasalahan yang esensial dalam penegakan hukum di Indonesia bukan hanya semata-mata terhadap produk hukum yang tidak responsif, melainkan juga berasal dari faktor aparat penegak hukumnya. Untuk meletakkan pondasi penegakan hukum, maka pilar yang utama adalah penegak hukum yang mampu menjalankan tugasnya dengan integritas dan dedikasi yang baik. Karena sepanjang sapu kotor belum dibersihkan, maka setiap pembicaraan tentang keadilan akan menjadi omong kosong belaka, as long as the dirty broom is not cleaned, any talk of justice will be empty (Yadyn, Abdul Razak, Aswanto : 3)

Laporan penilaian dan akuntabilitas pelaksanaan penegakan hukum di Indonesia menunjukkan bahwa tingkat kepercayaan masyarakat Indonesia terhadap penegakan hukum di Indonesia di bawah 60\% (enam puluh) persen (Jaringan Survei Indonesia, 2011). Itu artinya masyarakat kurang percaya terhadap sistem hukum dan aparat penegak hukum di Indonesia. Untuk melaksanakan penegakan hukum yang baik maka diharapkan aparat penegak hukum tidak sekedar menjadi boneka undangundang, yang melaksanakan ketentuan undang-undang secara normatif semata, melainkan dibutuhkan Common Sense yang baik oleh aparatur penegak hukum. Common Sense mengedepankan prinsip Sense Of Humanity yang dibutuhkan oleh aparat penegak hukum dalam penanganan suatu perkara agar ke depan tidak terjadi lagi perkara Minah-minah yang lain. Mengedepankan peraturan sebagai sesuatu yang serius adalah suatu seni yang kasuistis dan suatu semangat pembelaan hukum (lawyerly virtue) yang ambigu. (.(Ahmad Ali, 2001-74).

Kumpul kebo telah menimbulkan suatu keresahan bagi masyarakat karena dianggap sebagai suatu perbuatan yang menyimpang dari nilai-nilai yang ada didalam masyarakat, "Perbuatan kumpul kebo dianggap sebagai suatu perbuatan yang tidak pantas dan tidak benar untuk dilakukan serta bertentangan dengan moral masyarakat Indonesia." Berkaitan dengan hal 
tersebut, ditegaskan bahwa memang perbuatan kumpul kebo adalah perbuatan yang menyimpang serta bertentangan dengan nilai serta norma-norma yang berlaku dalam masyarakat. Perbuatan kumpul kebo dianggap sebagai salah satu dari kejahatan, karena dianggap kumpul kebo dapat menimbulkan suatu kejahatan baru atau lanjutan (factor kriminogen) seperti, aborsi, pembunuhan bayi yang lahir tidak diinginkan maupun pembuangan bayi sebagai hasil akibat adanya perbuatan kumpul tersebut. Akibatnya banyak kasus kumpul kebo yang diselesaikan secara brutal dan main hakim sendiri (eigenrechting) oleh masyarakat yang mendapati kasus ini di tempat mereka tinggal dan menetap.

Di dalam upaya penanggulangan kejahatan seperti kumpul kebo, terdapat banyak cara atau usaha yang dapat dilakukan untuk menanggulanginya. Salah satu dalam penanggulangan kejahatan adalah dengan menggunakan hukum pidana dengan sanksinya yang berupa pidana. Sejalan dengan hal tersebut Barda Nawawi Arief berpendapat bahwa, "kebijakan dalam penanggulangan kejahatan menggunakan hukum pidana pada hakikatnya merupakan bagian dari dari kebijakan penegakan hukum (khususnya hukum pidana)"(TeguhPrastya: 19).

Penegakan hukum yang dilakukan dalam menanggulangi kejahatan kumpul kebo dapat dilakukan dengan menggunakan sarana politik kriminal (criminal policy). Secara garis besar penanggulan kejahatan melalui politik kriminal (criminal policy) dapat dibagai menjadi 2 yaitu melalui jalur Penal atau hukum pidana dan melalui jalur Non-Penal atau bukan/diluar jalur hukum pidana.

Upaya penanggulangan kejahatan melalui jalur Penal lebih menitikberatkan pada sifat represif (Penindasan, pemberantasan, penumpasan) sesudah kejahatan terjadi, sedangkan jalur Non-Penal lebih menitikberatkan kepada sifat preventif (Pencegahan, penangkalan, penumpasan) sebelum kejahatan terjadi. (Barda Nawawi Arief, 2011: 19). 
Penegakan hukum di Indonesia pada saat ini dalam menanggulangi perbuatan kumpul kebo apabila menggunakan media penaltidak dapat dilakukan. Hal ini dikarenakan, apabila diketemukan kasus kumpul kebo yang kemudian dibawa ke ranah hukum, para aparat penegak hukum akan mengalami kesulitan karena tidak adanya satu Pasal pun dalam KUHP atau peraturan perundang-undangan yang mengatur secara jelas tentang perbuatan kumpul kebo atau recht vacuum. Hanya perbuatan zina saja yang diatur dalam Pasal 284 KUHP.

Peraturan yang satu-satunya dapat digunakan untuk mengatasi permasalahan tersebut adalah peraturan yang mengatur tentang tindak pidana ringan seperti Peraturan Daerah tentang Keamanan dan Ketertiban Masyarakat ataupun Peraturan Daerah tentang Perbuatan Asusila. Akan tetapi tidak di semua daerah terdapat pengaturan Perda ini dan disetiap daerah memiliki Perda yang berbeda antara daerah yang satu dengan yang lainnya. Dalam Peraturan Daerah tentang Keamanan dan Ketertiban Masyarakat ataupun Peraturan Daerah tentang Perbuatan Asusila yang berlaku tersebut ada yang mengatur mengenai kumpul kebo tetapi ada pula yang tidak menyinggungnya.

Adapun salah satu daerah yang sudah memulai menerapkan pengaturan tentang kumpul kebo yaitu antara lain Batam. Di daerah ini pelaku kumpul kebo diatur diatur Perda No. 6 tahun 2002, tentang "Ketertiban Sosial". Pengaturan terhadap perbuatan kumpul kebo diatur dalam Pasal 7 ayat (3) yang berbunyi: "Setiap orang berlainan jenis kelamin dilarang tinggal dan atau hidup satu atap layaknya suami istri tanpa diikat oleh perkawinan yang sah berdasarkan Undang-Undang. Terkait dengan ketentuan pidana terdapat dalam Pasal 16 ayat (1) yang berbunyi: "Pelanggaran terhadap ketentuan-ketentuan dalam Peraturan Daerah ini diancam dengan pidana kurungan paling lama 3 (tiga) bulan dan atau denda paling banyak Rp. 5.000.000,- (Lima Juta Rupiah). 
Praktik penegakan hukum selama ini masih banyak aparat penegak hukum yang menggunakan jalur non-penal karena pemerintah belum membuat suatu kebijakan hukum pidana atau suatu peraturan perundangundangan sebagai upaya penanggulangan perbuatan kumpul kebo melalui jalur Penal. Upaya Non-Penal yang dilakukan selama ini oleh aparat hukum apabila mengetahui terdapat kejahatan kumpul kebo hanya dibawa ke kantor polisi untuk didata dan diberikan pengarahan atau sosialisasi saja. Jarang sekali melihat perbuatan kumpul kebo ini dibawa sampai ke ranah hukum.

Upaya Non-Penal yang telah dilaksanakan di Indonesia menurut Sudarto yaitu "kegiatan patroli, kegiatan razia dari polisi yang dilakukan secara kontinu di tempat tertentu dan kegiatan tersebut berorientasi kepada pelayanan masyarakat atau kegiatan komunikatif edukatif masyarakat. Selain itu upaya Non-Penal dapat memanfaatkan kemajuan teknologi dan media massa". (Barda Nawawi Arief, 2011: 53).

\section{Kebijakan Formulasi Perbuatan Kumpul Kebo (Cohabitation) di Dalam Hukum Pidana di Masa yang Akan Datang}

Norma kesusilaan masyarakat Indonesia berbeda-beda dan beragam, hal ini dikarenakan di Negara Indonesia tumbuh berbagai macam suku bangsa dimana mereka hidup dengan adat istiadatnya masing-masing. Maka dari itu memang dirasa sulit menentukan kriteria atas penilaian rasa kesusilaannya. Akan tetapi dapat disimpulkan bahwa rasa kesusilaan dapat dinilai dari rasa ketidaksukaan masyarakat atas suatu perbuatan yang dianggap menyimpang dari nilai yang ada di dalam masyarakat disuatu daerah, salah satunya yaitu perbuatan kumpul kebo. Selama inipun di kampung-kampung berlaku norma yang menolak pelanggaran seperti itu, sehingga pelakunya acapkali digrebek petugas hansip dan warga yang merasa terganggu. Besar kecilnya keinginan masyarakat itu untuk menindak pelaku kumpul kebo menjadikan patokan nilai rasa kesusilaan masyarakat atas perbuatan kumpul kebo tersebut. 
Menurut Bassiouni, keputusan untuk melakukan kriminalisasi atau dekriminalisasi harus didasarkan pada faktor-faktor kebijakan tertentu yang mempertimbangkan berbagai faktor, termasuk:

a. The proportionality of the means used in relationship to the outcome obtained (keseimbangan sarana-sarana yang digunakan dalam hubungannya dengan hasil yang dicari atau yang ingin dicapai);

b. The cost analysis of the outcome in relationship to the objectives sought (analisis biaya terhadap hasil-hasil yang diperoleh dalam hubungannya dengan tujuan-tujuan yang dicari);

c. The appraisal of the objectives sought in relationship to other priorities in the allocation of resources of human power (penilaian terhadap tujuan-tujuan yang dicari dalam kaitannya dengan prioritasprioritas lainnya dalam pengalokasian sumber-

sumber tenaga manusia);

d. The social impact of criminalization and decriminalization in term of its secondary effects (pengaruh sosial dari kriminalisasi dan dekriminalisasi yang berkenaan dengan pengaruh-pengaruh sekunder). (M. Cherif Bassiouni : 82)

Sampai saat ini memang masih terdapat silang pendapat mengenai dibuatnya aturan mengenai kumpul kebo (cohabitation), akan tetapi dalam RKUHP Tahun 2012, kumpul kebo dicoba dirumuskan menjadi suatu perbuatan yang dianggap merupakan suatu perbuatan pidana. Adapun rumusannya yang terdapat pada Pasal 485 RKUHP adalah sebagai berikut: "Bahwa Setiap orang yang melakukan hidup bersama, sebagai suami istri di luar perkawinan yang sah, dipidana pidana penjara paling lama 1 (satu) tahun atau pidana denda paling banyak Kategori II".

Dalam kaitannya dengan politik kriminal (criminal policy), politik hukum bertugas meneliti perubahan mana yang perlu diadakan terhadap hukum yang ada agar memenuhi kebutuhan baru dalam kehidupan 
masyarakat. Politik hukum tersebut meneruskan arah perkembangan tertib hukum dari ius constitutum (hukum positif) menuju ius constituendum (hukum yang dicita-citakan). Politik hukum tidaklah berhenti setelah dikeluarkannya undang-undang, tetapi justru di sinilah mulai timbul persoalan, baik yang sudah diperkirakan sejak semula atau masalahmasalah lain yang timbul dengan tidak diduga-duga. Tiap undang-undang memberikan jangka waktu yang lama untuk dapat memberikan kesimpulan seberapa jauh tujuan politik hukum undang-undang tersebut telah dicapai. Jika hasilnya sulit untuk dicapai, apakah perlu diadakan perubahan atau penyesuaian seperlunya. Kemudian dengan pertimbangan bahwa apalah artinya terbentuknya suatu undang-undang tanpa adanya aplikasi dan review. Dengan adanya aplikasi dan review tujuan dari pembuatan undangundang itu akan dapat dicapai, karena politik hukum adalah suatu proses pencapaian tujuan masyarakat melalui undang-undang. (Program Pascasarjana Unisma : 18-30).

Terkait dengan dimasukkannya kumpul kebo ke dalam RKUHP, akhir-akhir ini muncul pendapat antara pendapat pro dan kontra. Kritik dari pandangan kontra menyatakan bahwa di banyak Negara masalah susila tidak pernah dipersoalkan karena memang Negara tidak berhak untuk mengurusi moral dan rasa kesusilaan masyarakat dan diaturnya masalah kumpul kebo ini berarti memasuki ranah kehidupan seks pribadi (individu), sedangkan menurut pendapat pro mengatakan sebagai berikut, bahwa kumpul kebo merupakan suatu realitas sosial dan memunculkan problem sosial, akan tetapi tidak ada aturannya dan belum terjamah oleh hukum. Oleh karena itu wajar kiranya jika diwadahi dalam wadah peraturan yang lebih konkrit. "Bahwa ide dasar yang mendasari perbuatan kumpul kebo dijadikan sebagai suatu perbuatan menyimpang atau perbuatan pidana adalah karena kondisi bangsa Indonesia yang religious menganggap perbuatan kumpul kebo bertentangan dengan nilai-nilai agama yang mereka anut". 
Sehubungan dengan pro dan kontra tersebut, maka akan dikemukakan beberapa latar belakang pemikiran atau dasar pertimbangan konsep KUHP mengangkat perbuatan kumpul kebo sebagai suatu tindak pidana dan dimasukkan sebagai salah satu delik kesusilaan.

Perbuatan yang berkaitan dengan kumpul kebo, dilihat dari nilai-nilai kesusilaan nasional merupakan perbuatan yang tidak sesuai dan bertentangan dengan prinsip dan falsafah yang menjiwai pancasila(Sholehuddin, 2003: 106).

Untuk selanjutnya akan dipaparkan terkait dengan kajian komparasi terkait perbuatan kumpul kebo di KUHP berbagai Negara di dunia :

1. KUHP Singapura dan Malaysia

Dalam Bab XX tentang “Offences Relating to Merriage”, ada Pasal yang mengancam pidana terhadap seorang laki-laki yang hidup bersama sebagai suami istri (cohabitation), atau melakukan hubungan seksual dengan seorang wanita yang karena ditipu telah percaya bahwa ia (wanita itu) telah kawin secara sah dengan laki-laki itu. (Pasal 493) Dalam Pasal 493 KUHP Singapore itu berbunyi: "Every man who by deceit causes any woman who is not lawfully married to him to believe that she is lawfully married to him and to cohabit or have sexual intercourse with him in that belief, shall be punished with imprisonment for a term which may extent to ten years, and shall also be liable to fine. Yang artinya: "Setiap lelaki yang dengan tipuan menyebabkan seorang wanita yang bukan istrinya yang sah percaya bahwa ia adalah istri yang sah dari laki-laki itu, dan hidup bersama atau melakukan hubungan seksual dengan dia atas kepercayaan tersebut, diancam pidana selama tidak lebih dari 10 tahun penjara dan juga denda”.

Selanjutnya dalam Pasal 493 Kanun Keseksaan (KUHP) Malaysia berbunyi: "Sasaorang lelaki yang dengan jalan perdayaan menyebabkan sasaorang perempuan yang tidak berkahwin dengannya dengan sah disisi undang-undang supaya memperchayai bahawa perempuan itu telah berkahwin dengannya dengan sah disisi undang-undang dan supaya 
bersekududokan atau bersetuboh dengannya atas keperchayaan itu, hendaklah diseksa dengan penjara selama tempoh yang boleh sampai duapuloh (sic.) tahun, dan bolehlah juga dikenakan denda”. Yang artinya: "Seorang laki-laki yang dengan cara memperdaya atau menipu seorang wanita yang tidak terikat dalam perkawinan yang sah dengannya menurut undang-undang, sehingga percaya bahwa ia telah menikah secara sah dengan laki-laki itu, dan hidup bersama atau melakukan persetubuhan dengannya atas kepercayaan tersebut, diancam pidana penjara selama tidak lebih dari 20 (sic. 10 tahun) dan juga denda”. (Barda Nawawi Arief, 2011: 310).

Dengan adanya rumusan Pasal 493 dalam KUHP Singapore maupun Malaysia tersebut maka jelas kedudukan perbuatan kumpul kebo atau cohabitation merupakan suatu tindak pidana yang secara jelas dan nyata oleh undang-undang diancam dengan pidana penjara sebagaimana diatur dalam Pasal tersebut.

\section{KUHP Fiji}

Pengaturan mengenai kumpul kebo di Negara kepulauan Fiji terdapat dalam Pasal 184. Di dalam Pasal 184 ini berisi antara lain: “Any Person who willfully and by fraud causes any woman who is not lawfully married to him to believe that she is lawfully married to him and to cohabit or have sexual intercourse with him in that belief, is guilty of a felony, and is liable to imprisonment for ten years". (Barda Nawawi Arief, 2011: 311).Yang artinya: "Siapapun yang dengan sengaja dan oleh penipuan menyebabkan setiap perempuan yang tidaklah dengan sah dinikahinya untuk percaya bahwa dia dengan sah dinikahinya dan untuk kumpul kebo atau melakukan hubungan seksual dengan dia didalam kepercayaannya itu, adalah bersalah atas suatu kejahatan, dan adalah dapat dikenakan hukuman penjara untuk sepuluh tahun".

Pengaturan mengenai kumpul kebo di KUHP Negara Kepulauan Fiji sama halnya dengan pengaturan kumpul kebo di Negara-negara bekas koloni 
Inggris, yaitu mengatur mengenai seorang laki-laki yang hidup sebagai suami istri dengan seorang wanita, dimana wanita itu adalah percaya bahwa laki-laki telah mengawininya secara sah. Hukuman bagi pelaku kumpul kebo di KUHP Negara kepulauan Fiji ini pun sama yaitu paling lama 10 tahun penjara.

Dengan adanya suatu kajian komparasi tersebut bertujuan sebagai wawasan terhadap sistem hukum Negara lain. Namun perlu diingat bahwa kajian komparasi dipergunakan untuk mengetahui bahwa memang KUHP di Negara lain pada kenyataannya telah mengatur perbuatan kebo. Pada akhirnya jika memang perbuatan kumpul kebo akan di jadikan suatu delik dan akan diakomodir dalam suatu peraturan hukum maka haruslah berdasarkan kepada nilai-nilai nasional.

Dengan diaturnya masalah kumpul kebo di berbagai KUHP Negara lain, berarti Negara lain (asing) juga mengurusi masalah moral dan rasa kesusilaan masyarakat. Jadi tidak benar adanya pendapat seperti yang dikemukakan diawal bahwa di banyak Negara masalah susila tidak pernah dipersoalkan karena Negara tidak berhak mengurusi moral dan rasa kesussilaan masyarakatnya. Sangat tepat kiranya pendapat D.A Thomas yang menyatakan, secara garis besar bahwa:

Sistem Hukum Pidana Substantif (KUHP) secara politik pada hakikatnya merupakan ciri simbolis dari ekspresi atau pernyataan kesatuan nasional istilah nasional juga dapat diidentikkan dengan kesepakatan nasional, dan secara moral merupakan perwujudan atau manifestasi penilaian masyarakat terhadap nilai-nilai sentral yang mengikat dan membatasi perilaku anggota masyarakat. (Barda Nawawi Arief, 2011: 314).

\section{Simpulan}

Berdasarkan permasalahan yang penulis kaji, dapat disampaikan simpualn sebagai berikut : 
1. Kebijakan hukum pidana saat ini belum menyentuh perbuatan kumpul kebo. Sehingga belum dapat untuk menjerat pelaku kumpul kebo. Sehingga perlu adanya perbaikan terhadap KUHP yang berlaku saat ini yang hanyalah terjemahan dari $\mathrm{WvS}$.

2. Penyusunan RKUHP dalam menjadikan perbuatan kumpul kebo sebagai salah satu dari delik kesusilaan tidak dapat dilepaskan dari ide dasar yang berlandaskan Pancasila sebagai nilai-nilai berkehidupan kebangsaan yang dicita-citakan. Dilihat dari nilai-nilai kesusilaan nasional, perbuatan yang berkaitan dengan kumpul kebo merupakan perbuatan yang tidak sesuai dan bertentangan dengan prinsip dan falsafah yang menjiwai pancasila serta bertentangan dengan agama yang dianut di Indonesia. Bahkan di dalam kajian komparatif membuktikan bahwa di Negara lain juga menentang perbuatan kumpul kebo karena dianggap sebagai perbuatan yang tidak patut untuk dilakukan.

\section{E. Daftar Pustaka}

\section{Buku-buku:}

Ahmad Ali. 2001. Keterpurukan hukum di Indonesia, Penyebab dan solusinya, Ghalia Indonesia.

Barda Nawawi Arief. 2013. Kapita Selekta Hukum Pidana. Bandung: Citra Aditya Bakti.

2010. Masalah Penegakan Hukum dan Kebijakan Hukum Pidana dalam Penanggulangan Kejahatan. Jakarta: Kencana.

1994. Beberapa aspek Pengembangan Ilmu Hukum Pidana (Menyongsong Generasi Baru Hukum Pidana Indonesia). Semarang : FH Undip

2011. Bunga Rampai Kebijakan Hukum Pidana (Perkembangan Penyusunan Konsep KUHP Baru). Jakarta: Kencana.

Hasan Alwi. 2007. Kamus Besar Bahasa Indonesia. Jakarta: Balai Pustaka.

Hendry Cambell. 1990. Black Law Dictionary. St. Paul : West Publishing. 
I.P.M Ranuhandoko. 1996. Terminologi Hukum Inggris-Indonesia. Jakarta: Sinar Grafika.

Komisi Yudisial. 2010. Dialektika Pembaharuan Sistem Hukum Indonesia. Jakarta: KY.

M. Cherif Bassiouni. 1978. Substantive Criminal Law, Charles C. Thomas Publisher, USA

Muladi. 1984. Lemabaga Pidana Bersyarat. Bandung : Alumni.

Sholehuddin. 2003. Sistem Sanksi dalam Hukum Pidana (Ide Dasar Double Track Sistem dan Implementasinya). Jakarta : Raja Grafindo

Simorangkir. 2009. Kamus Hukum. Jakarta: Sinar Grafika.

Soesilo. 1995. Kitab Undang-Undang Hukum Pidana (Serta Komentarnya Lengkap Pasal Demi Pasal). Bogor : Politea

Sudarto. 1981. Hukum dan Hukum Pidana. Bandung: Alumni.

1974. Suatu Dilema dalam Pembaharuan Sistem Pidana Indonesia. Semarang : FH Undip 2009. Hukum Pidana I. Semarang: Yayasan Soedarto.

Sudikno Mertokusumo. 2008. Mengenal Hukum (Suatu Pengantar). Yogyakarta: Liberty.

Syamsudin. 2012. Budaya Hukum Hakim Berbasis Hukum Progresif. Jakarta : Kencana Prenada Media Group.

Teguh Prasetya. 2012. Politik Hukum Pidana (Kajian Kebijakan Kriminalisasi dan Dekriminalisasi). Yogyakarta: Pustaka Pelajar.

\section{Jurnal:}

Eko Soponyono. 2013. Kebijakan Kriminalisasi “Kumpul Kebo" dalam Pembangunan Hukum Pidana di Indonesia, Masalah-Masalah Hukum Jilid 42 tahun 2013, p-ISSN :2086-2695, Fakultas Hukum Universitas Diponegoro.

Yadyn, Abdul Razak, Aswanto. 2015. Problematika Penegakan Hukum di Indonesia Menuju Hukum yang Responsif berdasarkan Nilai-Nilai Pancasila, Hasanudin Law Review. Program Pascasarjana Universitas Hasanuddin. 